\title{
Bullying by Prison Guards and the Emotional Progression of Minor Prisoners in Cameroon
}

\author{
LyongaMarlvinNjie ${ }^{1}$ and Ayonghe Lum Suzanne, $\mathbf{P h D}^{\mathbf{2}^{*}}$ \\ ${ }^{I}$ Faculty of Education, Department of Educational Psychology, University of Buea, Cameroon, \\ ${ }^{2}$ Advanced School of Translators and Interpreters (ASTI), Translation Division, University of Buea, Cameroon, \\ *Corresponding Author:Ayonghe Lum Suzanne, PhD,Advanced School of Translators and Interpreters \\ (ASTI), Translation Division, University of Buea, Cameroon,
}

\begin{abstract}
This study investigates the effects of bullying by prison guard on the emotional progression of minor prisons in Cameroon. The mixed method research design with sequential explanatory approach was adopted for the study. Data was collected from across four prisons (Buea, Douala, Mbalmayo and Kumba). A questionnaire, an interview guide and a check list were used for data collection. Emotional Maturity Scale constructed by Yashvir Singh and Mahesh Bhargava (2005) was used in the present study and Bullying was assessed using a nine-item categorical index adapted from Rigby and Slee (1995). The Reliability analysis of the instrument stood at 0.755 and was tested using the Cronbach alpha test. Both qualitative and qualitative data were collected for the study. The quantitative data were analysed using frequency counts, percentages, multiple responses set which aimed at calculating the summary of findings while hypotheses of study were tested using a parametric test; Pearson test while the qualitative data to be derived from the semi-structured interview guide were analysed using the thematic analysis. Findings show that $73.1 \%$ of the minor prisoners strongly agreed and agreed that they are bullied by guards meanwhile $26.9 \%$ of them are not. There was a negative sign of the correlation value $(R)$ implies that bullying has a negative effect on the emotional progression of minor prisoners. For instance, most of them show more sign of regression rather than progression. The implication of these findings is that bullying has a significant and negative effect on the emotional progression of minor prisoners.
\end{abstract}

Keywords:Bullying, Prison Guards, Emotional Progression, Minor Prisoners.

\section{INTRODUCTION}

Many young children are imperiled by abuse, neglect, domestic, community violence and poverty. Without effective intervention and help, these children suffer, struggle, and fall into despair and hopelessness. Some young teens cannot manage the emotional, social, and psychological challenges of adolescence and eventually engage in destructive and violent behaviour. Sadly, many have ignored the crisis and dysfunction that create child delinquency and instead have subjected kids to further victimization and abuse in the adult criminal justice system (Abrams, 2006).

Children are need a comfortable place to grow in and prisons are definitely not the place for any child. Generally,children sent to prison with the intention of rehabilitating so as to give them a second chance after reinsertion into the society but with all of this intention in mind, there is a high level of recivism amongst younger offenders (minors). Recidivism is measured by criminal acts that resulted in rearrests, reconviction or return to prison. Most times this has been justified by the fact that prison is a school of crimes.

\section{BACKGROUND}

The authorities of the former west Cameroon in the early 1960s considered socially maladjusted children as young criminals and put them together with adult criminals in the Buea central prison. Adult criminals were considered individuals above the age of 18 , old enough to take full responsibility for their actions and therefore could be tried before a court and sentenced to serve a length of time in prison for crimes they committed. This was done with the risk of the former (adult prisoners) contaminating the latter (minor prisoners). This was also done because of the lack of a rehabilitation centre in the country. 
This was also done because of the lack of a rehabilitation centre in the country. The only rehabilitation centre for maladjusted children in the territory was in Lagos and Enugu Nigeria (MINAS, 2015).The movement of these children from Cameroon to Nigeria involved a lot of risk and cost. Some rehabilitators believed that keeping maladjusted children in their own environments, (Cameroon) will go a long way to reduce the psychic torment which they suffered from being carried away so far from home with no chance of seeing a familiar face or environment. This consideration provided the fertile ground for the idea of the creation of the rehabilitation centre for the maladjusted children in Buea, Cameroon.

But even with the creation of the Borstal institute, many children find themselves in prison and this is because of the fact firstly we don't have a juvenile court in Cameroon, and secondly because even after the ratification of international human rights laws regarding children the Cameroon penal code and permit the imprisonment of children inn a special section of the prison.

One of the most important goals of any prison is to help the prisoners change their criminal behaviour and avoid re-offending after release. Consequently, prisons should offer a number of rehabilitation programs (Hollin,1999). It is important that the professionals providing these programs hold positive attitudes towards the prisoners. In this context, positive attitudes signify a view of prisoners as normal persons capable of positive change, whereas negative attitudes signify a view of prisoners as incurably deviant individuals Melvin, Gramling \&Gardner, (1985)

What correctional staff think about prisoners and how they behave towards them has a profound effect upon the prison environment. "A hostile, superior, contemptuous, or dismissive attitude on the part of a staff member constitutes an attack on the prisoner's self-esteem and inspires resentment both against the staff member and against the values and standards which he symbolises" (Hawkins, 1976 as cited in Liebling and Arnold 2004). Liebling and Arnold's interviews with prisoners and prison staff noted that 'in 'good' prisons, relationships between staff and prisoners provide the glue which holds establishments together" and that the reverse is also the case (Liebling and Arnold 2004: 229).

Prison officers' attitudes towards prison inmates are important especially when it concerns minors. Positive attitudes held by prison officers have been shown to be critical in facilitating change prior to successful release from prison (Glaser,1969). Prison officers are in a day-to-day interaction with the inmates and in this unique situation they have the power to enhance or undermine the primary goals of the correctional institution where they work. The prison officers' work situation has been described as psychosocially taxing (Schaufeli \& Peeters,2000).

\section{LITERATURE REVIEW}

Bullying is constant unwanted behaviour such as criticism, nit-picking, exclusion, isolation, being shouted at, being humiliated, and name-calling. It is a more concise definition of verbal abuse mainly done among peers (Howells-Johnson, 2000). It is found that, when dealing with students, it is normally a weaker child that is being verbally abused but sometimes physically bullied by a stronger child (Perry, Kusel\& Perry, 1988). This verbal bullying from peers has resulted in individuals having lower self-esteem, lower self-worth, feeling helpless, and having the feeling that they lack control over their feelings and actions (Bogart, Elliott, Klein, Tortolero, Mrug ,Peskin, Davies, Schink\& Schuster,2014).

Lines (1999) goes as far as to say that those individuals that are bullied lack confidence and for the rest of their life are affected with low self-esteem. These individuals start to accept and believe what is being said about them, even if the individual that is verbally bullying is significant or not, which results in the lowering of self-esteem and self-confidence (Lines, 1999).

The term 'bullying' is a specific form of victimization, discreet from other forms of harmful behaviour such as physical violence. There has been much debate regarding the key elements of 'bullying' and how prison bullying should be defined

Farrington, 1993; Connell and Farrington, 2016; Ireland, 2002b, Edgar, 2005; Edgar et al, 2003). Her Majesty's Prison Service (2004) defines bullying as: Conduct motivated by a desire to hurt, threaten, or frighten someone. It can be physical, verbal, psychological, emotional, or economical and often very subtle. It is usually repeated behaviour, unprovoked, and intended to cause fear or harm to the victim. Bullying cannot be mutual: it always involves a power imbalance. This distinguishes bullying from fights and assaults. 
Prison bullying was largely unstudied until the 1990s and initially, much of the research focused on documenting the nature of prison bullying, developing a specific, prison definition (as distinct from educational definitions of bullying), and understanding the involvement of prisoners in bullying. Although there has since been significantly more research on prison bullying, the phenomenon remains relatively unexplored, and the research has been largely driven by the psychological and quantitative tradition. Limited research focuses specifically on young adult prisoners (see Edgar et al, 2003; Ireland, 2002a; Ireland and Monaghan, 2006 for notable exceptions), which is particularly concerning given the identified links between bullying, self-harm, and deaths in custody amongst the juvenile and young adult population (Blauw et al, 2001; Prisons and Probation Ombudsman (PPO), 2013a, 2014).

According to James \&Rector (2018), bullying impacts a person's self-image. Verbal bullying hammers into its victims an identity that is worthless, incompetent, and unworthy. Carried on for long enough, by enough people, the victim begins to believe it or to erect defenses against it. These defenses can be many-layered. The victim begins to assume he (or she) is unable to get along with other people and incapable of being accepted. So, he simply rejects the world and the people in it and becomes a loner, untrusting to the point where he even rejects genuine overtures of friendship as probably a trick. As an adult, the individual will probably place a protective facade between himself and the rest of the world, dealing with those he encounters, deciding to have acquaintances rather than friends, using people rather than co-operating with them James \& Rector, (2018).

\section{EMotional Progression}

Emotional progression is the characteristic of a person that refers to a feeling of adequate advancement and going vitality of emotions concerning the environment to ensure positive thinking imbued with righteousness and contentment whereas, emotional regression is also a broad group of factors representing such syndromes as a feeling of inferiority, restlessness, hostility, aggressiveness, and self-centeredness. Inferiority complex is an exaggeration of normal inferiority feelings and individuals with inferiority complex display a tendency towards overcompensation and overreaction Heidbreder, (1927). Inferiority complex or lack of self-esteem leads to negative or risk-seeking behaviours in young people Moritz, (2006). Theoretical and correlational analyses have yielded tenuous associations between low self-esteem and socially problematic outcomes or risk-taking behaviours like substance abuse, aggression, and poor academic achievement

Dawes, (1994). Inferiority complex arises when a person finds himself in a situation where his/her abilities and attitudes are denigrated or rejected by other people (Ansbacher\&Ansbacher 1964). Anything in the individual that is below the average, provokes unfavorable comment or gives him/her a feeling of impotency or ineptitude leads to the inferiority complex (Murray 1938). The influence of values in one's life is very decisive. Values determine the kind of life one chooses to live. Values can be chosen consciously and measured and can become an instrument that permits the man to choose a new set of features rather than life in the direction some other persons (Kabir, Aziz, \&Jahan 2018).

Bronfenbrenner (1979) developed the ecological systems theory. He emphasized a balance between nature (heredity) and nurture (environment). To illustrate his theory, he depicts the child as surrounded by four concentric circles, each representing a different set of factors that influence the child. The four sections, from the innermost to the outermost: Micro-systems: is the individual, his friends, family, health, health services and other personal factors, Meso-system: this has to do with the interaction among the various settings of his or her immediate environment, Exo-system: this has to do with what is occurring in the setting in which he or she is present in this case the prison, Macrosystem: cultural attitudes and ideologies of his environment, These include the rules and regulations and even the outcomes of certain situations of the prison.

According to Vygotsky as explained by Miller (2011), humans are embedded within a socio-cultural matrix, and as such human behaviour can be understood within the cultural context in which people find themselves. The individual as such formulates new knowledge by changing old perceptions. According to Vygotsky (1978), this implies that a child potentially develops through problem-solving under adult guidance or collaboration with more knowledgeable peers. As such a learner moves from a lower level of reasoning to a higher one through clues, modelling, explanations, discussions, joint participation, etc. for this to occur, there must be a socio-cultural milieu within which the learner or individual child operates or interact. 


\section{Method}

This study was a mixed method, and specifically a sequential explanatory approach. This research was carried out in five different Regions of Cameroon. The population was made up of 200 minor inmates in Cameroon. The sample size was made up of 174 participants. These children were selected from 6 prisons in five regions of Cameroon.

Table1. Sample distribution: Distribution showing children in prison by demography

\begin{tabular}{|l|l|l|}
\hline Prison & Total population & Accessible population \\
\hline Buea Central Prison & 36 & 32 \\
\hline Kumba Provincial Prison & 22 & 22 \\
\hline Mbalmayo provincial prison & 10 & 10 \\
\hline Douala central prison & 33 & 33 \\
\hline Bafousam central prison & 32 & 30 \\
\hline Bamenda central prison & 41 & 41 \\
\hline Total & $\mathbf{1 7 4}$ & $\mathbf{1 7 2}$ \\
\hline
\end{tabular}

\section{Instrumentation}

The instrument used for data collection was a questionnaire, an interview guide and a check list. The questionnaire was adapted from some standardized tests for the purpose of the study. The items were selected because they were closely related to the variables of the study. After carefully selected, they were transformed into statements and adapted to suit the Likert scale so that the range of response could be easily converted to quantitative data to ease analyses.

Bullying was assessed using a nine-item categorical index adapted from Rigby and Slee (1998), Olweus (1996) and from the 2004 Youth Internet Survey (Ybarra \& Mitchell, 2004). Minors were asked how often they were bullied through physical (hit, kicked and pushed around; had money or other things broken or taken away from them; made to feel afraid they would get hurt).

Emotional progression was measured by adapting Emotional Maturity Scale constructed by Yashvir Singh and Mahesh Bhargava (2005).The scale consists of 48 items with five dimensions emotional progression having 10 items,

\section{FINDINGS}

Table2.Comparing respondents' opinion on prison staff bullying by prison and age range

\begin{tabular}{|c|c|c|c|c|c|c|}
\hline \multirow{2}{*}{\multicolumn{3}{|c|}{ Demographic information }} & \multirow{2}{*}{\multicolumn{2}{|c|}{ Bully by guards }} & \multirow{2}{*}{$\begin{array}{l}\text { Total } \\
\text { based on } \\
\text { MRS }\end{array}$} & \multirow{2}{*}{$\begin{array}{c}\text { Chi- } \\
\text { square } \\
\text { test }\left(\chi^{2}\right)\end{array}$} \\
\hline & & & & & & \\
\hline \multirow{9}{*}{$\begin{array}{l}\text { Name of } \\
\text { institution/ } \\
\text { prison }\end{array}$} & \multirow{3}{*}{$\begin{array}{l}\text { Douala central } \\
\text { prison }\end{array}$} & & \multirow{2}{*}{$\begin{array}{c}\begin{array}{c}\text { Strongly } \\
\text { Agree/Agree }\end{array} \\
154\end{array}$} & \multirow{2}{*}{$\begin{array}{c}\text { Disagree/Strongly } \\
\text { Disagree }\end{array}$} & & \\
\hline & & $\mathrm{n}$ & & & 232 & \multirow{8}{*}{$\begin{array}{c}\chi 2=1.71 \\
\mathrm{df}=3 \\
\mathrm{P}=0.633\end{array}$} \\
\hline & & $\%$ & $66.4 \%$ & $33.6 \%$ & & \\
\hline & \multirow{2}{*}{$\begin{array}{l}\text { Kumba } \\
\text { provincial } \\
\text { prison }\end{array}$} & $\mathrm{n}$ & 117 & 51 & 168 & \\
\hline & & $\%$ & $69.6 \%$ & $30.4 \%$ & & \\
\hline & \multirow{2}{*}{$\begin{array}{l}\text { Buea central } \\
\text { prison }\end{array}$} & $\mathrm{n}$ & 204 & 52 & 256 & \\
\hline & & $\%$ & $79.7 \%$ & $20.3 \%$ & & \\
\hline & \multirow{2}{*}{$\begin{array}{l}\text { Mbalmayo } \\
\text { provincial } \\
\text { prison }\end{array}$} & $\mathrm{n}$ & 69 & 19 & 88 & \\
\hline & & $\%$ & $78.4 \%$ & $21.6 \%$ & & \\
\hline \multirow{8}{*}{ Age range } & \multirow[t]{2}{*}{$12-13$ years } & $\mathrm{n}$ & 20 & 4 & 24 & \multirow{8}{*}{$\begin{array}{c}\chi^{2}=0.06 \\
\mathrm{df}=3 \\
\mathbf{P}=0.983\end{array}$} \\
\hline & & $\%$ & $83.3 \%$ & $16.7 \%$ & & \\
\hline & \multirow[t]{2}{*}{$14-15$ years } & $\mathrm{n}$ & 65 & 15 & 80 & \\
\hline & & $\%$ & $81.3 \%$ & $18.8 \%$ & & \\
\hline & \multirow[t]{2}{*}{$16-17$ years } & $\mathrm{n}$ & 355 & 133 & 488 & \\
\hline & & $\%$ & $72.7 \%$ & $27.3 \%$ & & \\
\hline & \multirow[t]{2}{*}{18 years } & $\mathrm{n}$ & 94 & 42 & 136 & \\
\hline & & $\%$ & $69.1 \%$ & $30.9 \%$ & & \\
\hline
\end{tabular}

Findings showed that irrespective of the prison and age range of the minor prisoners, findings showed that a majority of them in all the four prisons Douala central prison $66.4 \%$, Kumba provincial prison 69.6\%, Buea central prison $79.7 \%$ and Mbalmayo provincial prison $78.4 \%$ agreed that the prison staff do bully them with such incidence higher in the Buea central prison and Mbalmayo provincial prison than others. By age range, findings also showed that minor prisoners between 12-13 years of age are 
more bullied $83.3 \%$, followed by those $14-15$ years making a proportion of $81.3 \%, 16-17$ years $72.7 \%$ and lastly those 18 years $69.7 \%$ this phenomenon is general since the $p$-values are all $>0.05$.

Table3.Respondents opinion on bullying by prison staff

\begin{tabular}{|c|c|c|c|c|c|c|}
\hline \multirow[t]{2}{*}{ Opinion Statements } & \multicolumn{4}{|c|}{$\begin{array}{l}\text { Stretched } \\
\end{array}$} & \multicolumn{2}{|c|}{ Collapsed } \\
\hline & $\begin{array}{l}\text { Strongly } \\
\text { Agree } \\
\text { (SA) }\end{array}$ & $\begin{array}{l}\text { Agree } \\
\text { (A) }\end{array}$ & $\begin{array}{l}\text { Disagree } \\
\text { (D) }\end{array}$ & $\begin{array}{l}\text { Strongly } \\
\text { Disagree } \\
\text { (SD) }\end{array}$ & SA/A & D/SD \\
\hline $\begin{array}{l}\text { Am always bullied } \\
\text { through kicked and } \\
\text { pushed and shouted at be } \\
\text { the guards. }\end{array}$ & $\begin{array}{c}37 \\
(39.8 \%)\end{array}$ & $\begin{array}{c}19 \\
(20.4 \%)\end{array}$ & $\begin{array}{c}23 \\
(24.7 \%)\end{array}$ & $\begin{array}{c}14 \\
(15.1 \%)\end{array}$ & $\begin{array}{c}56 \\
(60.2 \%)\end{array}$ & $\begin{array}{c}37 \\
(39.8 \%)\end{array}$ \\
\hline $\begin{array}{l}\text { The guards take money or } \\
\text { other things from us; }\end{array}$ & $\begin{array}{c}36 \\
(38.7 \%)\end{array}$ & $\begin{array}{c}28 \\
(30.1 \%)\end{array}$ & $\begin{array}{c}16 \\
(17.2 \%)\end{array}$ & $\begin{array}{c}13 \\
(14.0 \%)\end{array}$ & $\begin{array}{c}64 \\
(68.8 \%)\end{array}$ & $\begin{array}{c}29 \\
(31.2 \%)\end{array}$ \\
\hline $\begin{array}{l}\text { The guards make us feel } \\
\text { afraid they would hurt us }\end{array}$ & $\begin{array}{c}40 \\
(43.0 \%) \\
\end{array}$ & $\begin{array}{c}30 \\
(32.3 \%)\end{array}$ & $\begin{array}{c}16 \\
(17.2 \%) \\
\end{array}$ & $\begin{array}{c}7 \\
(7.5 \%) \\
\end{array}$ & $\begin{array}{c}70 \\
(75.3 \%)\end{array}$ & $\begin{array}{c}23 \\
(24.7 \%) \\
\end{array}$ \\
\hline $\begin{array}{l}\text { The guards made fun of } \\
\text { and teased in a hurtful } \\
\text { way and call us bad and } \\
\text { hurtful names }\end{array}$ & $\begin{array}{c}45 \\
(48.4 \%)\end{array}$ & $\begin{array}{c}29 \\
(31.2 \%)\end{array}$ & $\begin{array}{c}7 \\
(7.5 \%)\end{array}$ & $\begin{array}{c}12 \\
(12.9 \%)\end{array}$ & $\begin{array}{c}74 \\
(79.6 \%)\end{array}$ & $\begin{array}{c}19 \\
(20.4 \%)\end{array}$ \\
\hline $\begin{array}{l}\text { The guards tell lies about } \\
\text { us and tried to make other } \\
\text { people not like us }\end{array}$ & $\begin{array}{c}41 \\
(44.1 \%)\end{array}$ & $\begin{array}{c}28 \\
(30.1 \%)\end{array}$ & $\begin{array}{c}9 \\
(9.7 \%)\end{array}$ & $\begin{array}{c}15 \\
(16.1 \%)\end{array}$ & $\begin{array}{c}69 \\
(74.2 \%)\end{array}$ & $\begin{array}{c}24 \\
(25.8 \%)\end{array}$ \\
\hline $\begin{array}{l}\text { The guards hurt some } \\
\text { children than others }\end{array}$ & $\begin{array}{c}44 \\
(47.3 \%)\end{array}$ & $\begin{array}{c}26 \\
(28.0 \%)\end{array}$ & $\begin{array}{c}10 \\
(10.8 \%)\end{array}$ & $\begin{array}{c}13 \\
(14.0 \%)\end{array}$ & $\begin{array}{c}70 \\
(75.3 \%)\end{array}$ & $\begin{array}{c}23 \\
(24.7 \%)\end{array}$ \\
\hline $\begin{array}{l}\text { I feel uncomfortable when } \\
\text { I watch someone being } \\
\text { bullied }\end{array}$ & $\begin{array}{c}44 \\
(47.3 \%)\end{array}$ & $\begin{array}{c}25 \\
(26.9 \%)\end{array}$ & $\begin{array}{c}11 \\
(11.8 \%)\end{array}$ & $\begin{array}{c}13 \\
(14.0 \%)\end{array}$ & $\begin{array}{c}69 \\
(74.2 \%)\end{array}$ & $\begin{array}{c}24 \\
(25.8 \%)\end{array}$ \\
\hline $\begin{array}{l}\text { It makes me angry when } \\
\text { someone is bullied. }\end{array}$ & $\begin{array}{c}37 \\
(39.8 \%)\end{array}$ & $\begin{array}{c}35 \\
(37.6 \%)\end{array}$ & $\begin{array}{c}13 \\
(14.0 \%)\end{array}$ & $\begin{array}{c}8 \\
(8.6 \%)\end{array}$ & $\begin{array}{c}72 \\
(77.4 \%)\end{array}$ & $\begin{array}{c}21 \\
(22.6 \%) \\
\end{array}$ \\
\hline $\begin{array}{lll}\begin{array}{l}\text { Multiple } \\
\text { (MRS) }\end{array} & \text { Response } & \text { Set } \\
\end{array}$ & $\begin{array}{l}324 \\
(43.5 \%)\end{array}$ & $\begin{array}{l}220 \\
(29.6 \%)\end{array}$ & $\begin{array}{l}105 \\
(14.1 \%)\end{array}$ & $\begin{array}{l}95 \\
(12.8 \%)\end{array}$ & $\begin{array}{l}544 \\
(73.1 \%)\end{array}$ & $\begin{array}{l}200 \\
(26.9 \%)\end{array}$ \\
\hline
\end{tabular}

In aggregate, findings showed that $73.1 \%$ of the minor prisoners strongly agreed and agreed that they are bullied by guards meanwhile $26.9 \%$ of them are not. To be explicit, findings showed that a majority of the minor prisoners $56(60.2 \%)$ agreed that they are always bullied through kicked with 64 $(68.8 \%)$ of them also agreed that the guards take money or other things from them. Findings also showed that a majority of the minor prisoners $70(75.3 \%)$ agreed that the guards make them to feel afraid, with 74 (79.6\%) of them also agreed that the guards made fun of them, teased in a hurtful way and call them bad and hurtful names. Findings also showed that a majority of the minor prisoners 69 (74.2\%) agreed that the guards tell lies against them and that they feel uncomfortable when someone is being bullied. Furthermore, a majority of the minor prisoners and $70(75.3 \%)$ agreed that the guards hurts some children more than them and $72(77.4 \%)$ of them in their majority also agreed that they feel angry when someone is bullied. The overall finding for bullying is also presented on the figure below.

Table4.Respondents opinion on emotional progression

\begin{tabular}{|c|c|c|c|c|c|c|}
\hline \multirow[t]{2}{*}{ Opinion Statements } & \multicolumn{4}{|c|}{ Stretched } & \multicolumn{2}{|c|}{ Collapsed } \\
\hline & $\begin{array}{c}\text { Strongly } \\
\text { Agree } \\
\text { (SA) }\end{array}$ & $\begin{array}{l}\text { Agree } \\
\text { (A) }\end{array}$ & $\begin{array}{l}\text { Disagree } \\
\text { (D) }\end{array}$ & $\begin{array}{l}\text { Strongly } \\
\text { Disagree } \\
\text { (SD) }\end{array}$ & SA/A & D/SD \\
\hline $\begin{array}{l}\text { If I fail to achieve my } \\
\text { goal, I feel inferior. }\end{array}$ & $\begin{array}{c}56 \\
(60.2 \%) \\
\end{array}$ & $\begin{array}{c}22 \\
(23.7 \%)\end{array}$ & $\begin{array}{c}10 \\
(10.8 \%)\end{array}$ & $\begin{array}{c}5 \\
(5.4 \%) \\
\end{array}$ & $\begin{array}{c}78 \\
(83.9 \%)\end{array}$ & $\begin{array}{c}15 \\
(16.1 \%)\end{array}$ \\
\hline $\begin{array}{l}\text { I experience a sense of } \\
\text { discomfort and lack of } \\
\text { peace of mind. }\end{array}$ & $\begin{array}{c}37 \\
(39.8 \%)\end{array}$ & $\begin{array}{c}33 \\
(35.5 \%)\end{array}$ & $\begin{array}{c}11 \\
(11.8 \%)\end{array}$ & $\begin{array}{c}12 \\
(12.9 \%)\end{array}$ & $\begin{array}{c}70 \\
(75.3 \%)\end{array}$ & $\begin{array}{c}23 \\
(24.7 \%)\end{array}$ \\
\hline $\begin{array}{l}\text { I indulge in mocking and } \\
\text { provoking others. }\end{array}$ & $\begin{array}{c}32 \\
(34.4 \%)\end{array}$ & $\begin{array}{c}18 \\
(19.4 \%)\end{array}$ & $\begin{array}{c}23 \\
(24.7 \%)\end{array}$ & $\begin{array}{c}20 \\
(21.5 \%)\end{array}$ & $\begin{array}{c}50 \\
(53.8 \%)\end{array}$ & $\begin{array}{c}43 \\
(46.2 \%)\end{array}$ \\
\hline $\begin{array}{l}\text { I try to put blame on } \\
\text { others for my mistakes. }\end{array}$ & $\begin{array}{c}22 \\
(23.7 \%)\end{array}$ & $\begin{array}{c}25 \\
(26.9 \%)\end{array}$ & $\begin{array}{c}23 \\
(24.7 \%)\end{array}$ & $\begin{array}{c}23 \\
(24.7 \%)\end{array}$ & $\begin{array}{c}47 \\
(50.5 \%)\end{array}$ & $\begin{array}{c}46 \\
(49.5 \%)\end{array}$ \\
\hline $\begin{array}{l}\text { When people don't agree } \\
\text { with me, I quarrel with }\end{array}$ & $\begin{array}{c}31 \\
(33.3 \%)\end{array}$ & $\begin{array}{c}31 \\
(33.3 \%)\end{array}$ & $\begin{array}{c}16 \\
(17.2 \%)\end{array}$ & $\begin{array}{c}15 \\
(16.1 \%)\end{array}$ & $\begin{array}{c}62 \\
(66.7 \%)\end{array}$ & $\begin{array}{c}31 \\
(33.3 \%)\end{array}$ \\
\hline
\end{tabular}


Bullying by Prison Guards and the Emotional Progression of Minor Prisoners in Cameroon

\begin{tabular}{|c|c|c|c|c|c|c|}
\hline them. & & & & & & \\
\hline I feel that I am exhausted. & $\begin{array}{c}38 \\
(40.9 \%)\end{array}$ & $\begin{array}{c}30 \\
(32.3 \%)\end{array}$ & $\begin{array}{c}9 \\
(9.7 \%)\end{array}$ & $\begin{array}{c}16 \\
(17.2 \%)\end{array}$ & $\begin{array}{c}68 \\
(73.1 \%)\end{array}$ & $\begin{array}{c}25 \\
(26.9 \%)\end{array}$ \\
\hline $\begin{array}{l}\text { My behaviour is more } \\
\text { aggressive than that of my } \\
\text { friends. }\end{array}$ & $\begin{array}{c}36 \\
(38.7 \%)\end{array}$ & $\begin{array}{c}29 \\
(31.2 \%)\end{array}$ & $\begin{array}{c}17 \\
(18.3 \%)\end{array}$ & $\begin{array}{c}11 \\
(11.8 \%)\end{array}$ & $\begin{array}{c}65 \\
(69.9 \%)\end{array}$ & $\begin{array}{c}28 \\
(30.1 \%)\end{array}$ \\
\hline $\begin{array}{l}\text { I get lost in the world of } \\
\text { imaginations. }\end{array}$ & $\begin{array}{c}43 \\
(46.2 \%)\end{array}$ & $\begin{array}{c}21 \\
(22.6 \%)\end{array}$ & $\begin{array}{c}16 \\
(17.2 \%)\end{array}$ & $\begin{array}{c}13 \\
(14.0 \%)\end{array}$ & $\begin{array}{c}64 \\
(68.8 \%)\end{array}$ & $\begin{array}{c}29 \\
(31.2 \%)\end{array}$ \\
\hline I am self-centered. & $\begin{array}{c}35 \\
(37.6 \%)\end{array}$ & $\begin{array}{c}24 \\
(25.8 \%)\end{array}$ & $\begin{array}{c}16 \\
(17.2 \%)\end{array}$ & $\begin{array}{c}18 \\
(19.4 \%)\end{array}$ & $\begin{array}{c}59 \\
(63.4 \%)\end{array}$ & $\begin{array}{c}34 \\
(36.6 \%)\end{array}$ \\
\hline $\begin{array}{l}\text { I am not satisfied with } \\
\text { myself. }\end{array}$ & $\begin{array}{c}41 \\
(44.1 \%)\end{array}$ & $\begin{array}{c}17 \\
(18.3 \%)\end{array}$ & $\begin{array}{c}10 \\
(10.8 \%)\end{array}$ & $\begin{array}{c}25 \\
(26.9 \%)\end{array}$ & $\begin{array}{c}58 \\
(62.4 \%)\end{array}$ & $\begin{array}{c}35 \\
(37.6 \%)\end{array}$ \\
\hline $\begin{array}{l}\text { Multiple Response Set } \\
\text { (MRS) }\end{array}$ & $\begin{array}{c}371 \\
(39.9 \%)\end{array}$ & $\begin{array}{c}250 \\
(26.9 \%)\end{array}$ & $\begin{array}{c}151 \\
(16.2 \%)\end{array}$ & $\begin{array}{c}158 \\
(17.0 \%)\end{array}$ & $\begin{array}{c}621 \\
(66.8 \%)\end{array}$ & $\begin{array}{c}309 \\
(33.2 \%)\end{array}$ \\
\hline
\end{tabular}

In overall, findings showed that $66.8 \%$ of the minor prisoners suffer from emotional regression while $33.2 \%$ of them do not. To be explicit, findings showed that a majority of the minor prisoners 78 $(83.9 \%)$ agreed that they feel inferior, with $70(75.3 \%)$ of them also agreed that they experience a sense of discomfort and lack of peace of mind. Findings also showed that $50(53.8 \%)$ of them agreed that they do indulge in mocking others, with 47 (50.5\%) of them also agreed to blame others for their mistakes.

Table5.Cross tabulation showing the effect of bullying on emotional progression

\begin{tabular}{|c|c|c|c|c|c|}
\hline & & & \multicolumn{2}{|c|}{ Emotional progression } & \multirow[t]{2}{*}{ Total } \\
\hline & & & $\begin{array}{c}\text { Suffering from } \\
\text { emotional regression }\end{array}$ & $\begin{array}{l}\text { Not suffering from } \\
\text { emotional regression }\end{array}$ & \\
\hline \multirow{4}{*}{$\begin{array}{l}\text { Suffering } \\
\text { from } \\
\text { bullying }\end{array}$} & \multirow{2}{*}{$\begin{array}{l}\text { Strongly } \\
\text { Agree/ } \\
\text { Agreed }\end{array}$} & $\mathrm{N}$ & 49 & 19 & 68 \\
\hline & & $\%$ & $72.1 \%$ & $27.9 \%$ & \\
\hline & \multirow{2}{*}{$\begin{array}{l}\text { Disagree/ } \\
\text { Strongly } \\
\text { Disagree }\end{array}$} & $\mathrm{N}$ & 13 & 12 & 25 \\
\hline & & $\%$ & $52.0 \%$ & $48.0 \%$ & \\
\hline \multicolumn{2}{|l|}{ Total } & $\mathbf{N}$ & 62 & 31 & 93 \\
\hline
\end{tabular}

Findings on the table showed that a majority of the minor prisoners suffering from emotional regression are mostly those who are being bullied by the guards making a proportion of $72.1 \%$ when compared to those who are not being bullied $52.0 \%$ and this difference is significant (Chi-square= 3.31, $\mathrm{df}=1, \mathrm{P}=0.068$ ).

\section{DISCUSSION}

Findings in this study have shown that bullying of minor prisoners by prison guards has a significant negative effect on the emotional progression of these minors, there by indicating that it has a negative effect on the development of emotional maturity.

These findings go in line with the findings of Blaauw, (2001). Bullying impacts upon individuals and the prison, creating disruptions that allow inmates to gain power and subvert prison rules (Home Office Prison Service, 1993). However, bullying poses problems beyond the confines of the establishment. If bullies are not challenged about their behaviour, they may learn that exploitation is a valuable strategy and so are unlikely to live law-abiding lives on release (Levenson, 2000).

The effects of bullying in this study go in line to support the assumptions made by Espelage, Bosworth \& Simon, 2000; Hoover, Oliver \& Thomson, 1993; Ireland, 2000; Oliver, Oaks \& Hoover, 1994; Peterson \& Skiba, 2001), that bullying behaviour may cause physical, oral or mental attacks against victims, thus it may easily and psychologically terrify and hurt victims.

Edgar et al, 2003; Ireland, 2002a; Ireland and Monaghan, 2006; for notable exceptions), which is particularly disturbinggiven that, they identified links between bullying, self-harm, and deaths in custody amongst the juvenile and young adult population (Blauw et al, 2001; Prisons and Probation Ombudsman (PPO), 2013a, 2014).

According to Heidbreder (1927), emotional regression is exhibited with factors such as syndromes of a feeling of inferiority, restlessness, hostility, aggressiveness, and self-centeredness. Inferiority complex is an exaggeration of normal inferiority feelings and individuals with inferiority complex 
display a tendency towards overcompensation and overreaction (Heidbreder, 1927). This was indicated in the findings since most of the minors agreed to feeling inferior. Inferiority complex or lack of self-esteem leads to negative or risk-seeking behaviours in young people (Moritz, 2006).

\section{CONCLUSION}

The findings show that bullying, has a negative effect on the development of emotional maturity. This can be seen as the correlation between bullying and emotional progression has a negative correlation meaning that they have a negative effect on each other. Thus, one of the indications of the findings is that prison guards are not prepared with the right tools to take care of the emotional and social requirements that go with the rehabilitation of minors in prison or any incarceration Centre.

The opinion of these guards about prisoners be it minors, or adult has a great role to play on their interaction and attitude towards the prisoner and this will determine how they interact, talk and behave with the children and also being conscious of the fact that whatever they say or do has either a positive or negative effect on the attitude, feeling and rehabilitation process of these children. this also goes a long way to support the school of thoughts that say children have no place in the adult prison system. This is because the prison will not only act as a school of crime but will also affect their emotional progression which is one of the main pillars of emotional maturity which is very important for later life functioning.

\section{REFERENCES}

[1] Abrams, L.S. (2006). Listening to juvenile offenders: Can residential treatment prevent recidivism? Child and Adolescent Social Work Journal, 23 (1), 61-85

[2] Hollin, C. R. (1999). Treatment programs for offenders: Meta-analysis, "What works," and beyond. International Journal of Law and Psychiatry, 22(3-4), 361-372. https://doi.org/10.1016/S01602527(99)00015-1

[3] Melvin, K. B., Gramling, L. K., \& Gardner, W. M. (1985). A scale to measure attitudes toward prisoners. Criminal Justice and Behaviour, 12(2), 241-253. https://doi.org/10.1177/0093854885012002006

[4] Liebling, A. (1992). Suicides in prison. London: Routledge. Lipsey M. W., (1992). Juvenile delinquency treatment: A meta-analytic inquiry into the variability of effects. In Cook T., Cooper H., Cordray D. S., et al. (Eds.), Meta-Analysis for Explanation (pp. 83--126). New York: Russell Sage Foundation.

[5] Glaser, R. (1973). Educational psychology and education. American Psychologist, 28(7), 557-566. https://doi.org/10.1037/h0034976

[6] Schaufeli, W. B., \&Peeters, M. C. W. (2000). Job stress and burnout among correctional officers: A literature review. International Journal of Stress Management, 7(1), 19-48. https://doi.org/10.1023/A:1009514731657

[7] Johnson, R. B., Onwuegbuzie, A. J., \& Turner, L. A. (2007). Toward a definition of mixed methods research. Journal of Mixed Methods Research, 1, 112-133. doi:10.1177/1558689806298224

[8] Perry, D. G., Kusel, S. J., \& Perry, L. C. (1988). Victims of peer aggression. Developmental Psychology, 24(6),

[9] Howells-Johnson, J. (2000). Verbal abuse. British Journal of Perioperative Nursing, 10(10):508-511. Huskinson, L. (2002).

[10] Bogart LM, Elliott MN, Klein DJ, Tortolero SR, Mrug S, Peskin MF, Davies SL, Schink ET, Schuster MA. (2014). Peer victimization in fifth grade and health in tenth grade. Pediatrics.;133(3):440-447. [PMC free article]

[11] Yashvir Singh and Mahesh Bharani (2005). Manual for Emotional Maturity Score, National Psychological Corporation, India, $1-15$.

[12] Rigby, K und Slee, P. T. (1995). The Peer Relations Questionnaire. Adelaide: University of South Australia.

[13] Blaauw, E., Winkel, F.W. and Kerkhof, A.J.F.M. (2001) 'Bullying and Suicidal Behaviour in Jails,' Criminal Justice and Behaviour, 29(3): 279-299

[14] Edgar, K. (2005) 'Bullying, Victimisation and Safer Prisons,' Probation Journal, 52(4): 390-400. Edgar, K., O’Donnell, I. and Martin, C. (2003) Prison Violence: The Dynamics of Conflict, Fear and Power. Willan

[15] Farrington, D.P. (1993) ‘Understanding and Preventing Bullying,' Crime and Justice, 17: 381- 458.

[16] Ireland, J. (2000) “'Bullying” among Prisoners: A Review of Research,' Aggression and Violent Behaviour, 5(2): 201-15. 
[17] Her Majesty’s Prison Service (2004) Violence Reduction: Prison Service Order 2750. London: HM Prison Service.

[18] Ireland, J. L. (2000). "Bullying” among prisoners: A review of research. Aggression and Violent, 5, 201215

[19] Oliver, R., Oaks, I. N., \& Hoover, J. H. (1994). Family issues and interventions in bully and victim relationships. School Counselor, 41, 199-203

[20] Peterson, R. L., \& Skiba, R. (2001). Creating school climates that pre-

[21] vent school violence. Clearing House, 74, 155-163

[22] Bosworth, K., \&Espelage, K. L., (1999). Factors associated with bully- ing behavior in middle school students. The Journal of Early Ado- lescence, 19, 341-363.

[23] Ireland, J. and Monaghan, R. (2006) 'Behaviours indicative of Bullying among Young and Juvenile Male offenders: A study of perpetrator and victim characteristics,' Aggressive Behaviour, 32(2): 172-180.

[24] Connell, A., Farrington, D.P. and Ireland, J.L. (2016), "Characteristics of bullies and victims among incarcerated male young offenders", Journal of Aggression, Conflict and Peace Research, Vol. 8 No. 2, pp. 114-123. https://doi.org/10.1108/JACPR-12-2015-0200.

[25] Heidbreder, E. (1927). Introversion and extroversion in men and women. The Journal of Abnormal and Social Psychology, 22(1), 52-61. https://doi.org/10.1037/h0074959.

[26] Moritz S. (2006). The inferiority complex in paranoia readdressed: a study with the

[27] Implicit Association Test.Cognitive Neuropsychiatry11 (4), 402-15.

[28] Moritz S. (2006). The inferiority complex in paranoia readdressed: a study with the

[29] Implicit Association Test.Cognitive Neuropsychiatry11 (4), 402-15.

[30] Moritz S. (2006). The inferioritycomplex in paranoia readdressed: a study with the Implicit Association Test. Cognitive Neuropsychiatry11 (4), 402-15.

[31] Dawes R.M. (1994). House of cards: Psychology and Psychotherapybuilt on myth. New-York Press: USA.

[32] Ansbacher H.L.\&Ansbacher R.R (1964): The Individual Psychology of Alfred Adler. New-York: Harper Torchbook.

[33] Murray H.A. (1938): Explorations in Personality. New-York: Oxford University Press.

[34] Kabir S.M.S., Aziz M.A., \& Jahan A.K.M.S. (2018). Women Empowerment and Governance in Bangladesh. ANTYAJAA: Indian journal of Women and Social Change, SAGE Publications India Pvt. Ltd, 3(1), 1-12.

[35] Bandura, A. (1977). Social Learning Theory. Englewood Cliffs, NJ: Prentice Hall.

[36] Bronfenbrenner U. 1979.The Ecology of Human Development. Experiments by Nature and Design. Harvard University Press: Cambridge, MA. Brooks F. 2002. Impact of child-care subsidies on family and child well-being. Early Childhood Research Quarterly 17: 498-511.

[37] Espelage, D. L., Bosworth, K., \& Simon, T. R. (2000). Examining the social context of bullying behaviors in early adolescence. Journal of Counseling \& Development, 78, 326-333.

[38] Hoover, J. H., Iver, R., \& Thomson, K. (1993). Perceived victimization by school bullies: New research and future directions. Journal of Humanistic Education and Development, 32, 76-84.

Citation: Ayonghe Lum Suzanne, PhD\&LyongaMarlvinNjie., "Bullying by Prison Guards and the Emotional Progression of Minor Prisoners in Cameroon" International Journal of Humanities Social Sciences and Education (IJHSSE), vol 8, no. 8, 2021, pp. 156-163. doi: https://doi.org/10.20431/2349-0381.0808015

Copyright: () 2021 Authors. This is an open-access article distributed under the terms of the Creative Commons Attribution License, which permits unrestricted use, distribution, and reproduction in any medium, provided the original author and source are credited. 